\title{
Evaluation of sclerotherapy with different dilutions of ethanolamine oleate in the treatment of oral varicose veins
}

\author{
Avaliação da escleroterapia com diferentes \\ diluições de oleato de etanolamina \\ no tratamento de varizes orais
}

\begin{abstract}
Bianca Montes MORAES1 iD https://orcid.org/0000-0002-4673-1920
Mariana Marinho ARÊDES' ID https://orcid.org/0000-0003-0280-6633

Cristiano Magalhães Moura VILAÇA² iD https://orcid.org/0000-0001-8176-2901

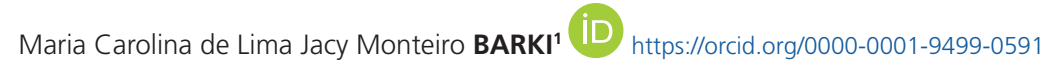

Juliana Tristão WERNECK' ${ }^{1}$ iD https://orcid.org/0000-0002-9828-0850

Karla Bianca Fernandes da Costa FONTES ${ }^{1}$ iD https://orcid.org/0000-0002-1669-6271

Bruna Lavinas Sayed PICCIANI,2,3 iD https://orcid.org/0000-0001-7592-1785
\end{abstract}

\section{ABSTRACT}

Objective: This study aim to evaluate the effectiveness of sclerotherapy protocols with different dilutions of ethanolamine oleate in the treatment of oral varicose veins. Methods: Clinical data and images of 14 cases treated with sclerotherapy were analyzed and descriptive analyses were performed. Results: Females (58\%) and white skin color (83\%) prevailed. Age varied between 14 and 79 years, with 47 years on mean (SD = 19 years). The most common anatomical locations were the buccal mucosa and lower lip. The final volume of the sclerosing agent (Ethamolin ${ }^{\circledR}$ ) ranged from 0.4 to $4.3 \mathrm{ml}$ and the concentration ranged from $5 \%$ to $100 \%$. The number of sessions ranged from 1 to 12 and the number of points per application was 1 to 7 points. Pain and edema were seen in $43 \%$ and $29 \%$ of patients, respectively. Conclusion: Sclerotherapy with monoethanolamine oleate diluted in anesthetic is a safe and effective option for the treatment of this lesion, regardless of concentration. However, edema and pain seem to be directly associated with increased drug concentration.

Indexing terms: Cerebrovascular trauma. Ethanolamine. Hemangioma. Sclerotherapy. Varicose veins.

\section{$\boldsymbol{\nabla} \boldsymbol{\nabla} \boldsymbol{\nabla}$}

1 Universidade Federal Fluminense, Faculdade de Odontologia, Departamento de Formação Específica. Nova Friburgo, RJ, Brasil.

2 Universidade Federal Fluminense, Instituto de Saúde de Nova Friburgo Nova Friburgo, Programa de Pós-graduação em Odontologia. Nova Friburgo, RJ, Brasil.

${ }^{3}$ Universidade Federal Fluminense, Faculdade de Medicina, Programa de Pós-Graduação em Patologia. Rua Marquês do Paraná, 303, $2^{\circ}$ andar, Prédio Principal, Centro, 24030-215, Niterói, RJ, Brasil. Correspondence to: BLS PICCIANI. E-mail: <brunapicciani@gmail.com>.

$\boldsymbol{\nabla} \boldsymbol{\nabla} \boldsymbol{v}$

How to cite this article

Moraes BM, Arêdes MM, Vilaça CMM, Barki MCLM, Werneck JT, Fontes KBFC, Picciani BLS. Evaluation of sclerotherapy with different dilutions of ethanolamine oleate in the treatment of oral varicose veins. RGO, Rev Gaúch Odontol. 2021;69:e20210043. http://dx.doi. org/10.1590/1981-863720210004320200090 


\section{RESUMO}

Objetivo: Este estudo tem como objetivo avaliar a efetividade de protocolos de escleroterapia com diferentes diluições de oleato de etanolamina no tratamento de varizes orais. Métodos: Dados clínicos e imagens de 14 casos tratados com escleroterapia foram avaliados, sendo realizado análises descritivas. Resultados: As mulheres (58\%) e a cor de pele branca (83\%) prevaleceram na amostra. A idade variou entre 14 e 79 anos, com média de 47 anos (DP = 19 anos). As localizações anatômicas mais comuns foram a mucosa jugal e o lábio inferior. O volume final do agente esclerosante (Ethamolin ${ }^{\circledR}$ ) variou de 0,4 a 4,3ml e a concentração variou de $5 \%$ a $100 \%$. O número de sessões variou de 1 a 12 e o número de pontos por aplicação foi de 1 a 7 pontos. Dor e edema foram observados em $43 \%$ e 29\% dos pacientes, respectivamente. Conclusão: A escleroterapia com oleato de monoetanolamina diluído em anestésico é uma opção segura e eficaz para o tratamento das varizes orais, independentemente da concentração. No entanto, edema e dor parecem estar diretamente associados ao aumento da concentração do medicamento.

Termos de indexação: Traumatismo cerebrovascular. Etanolamina. Hemangioma. Escleroterapia. Varizes.

\section{INTRODUCTION}

Vascular anomalies are classified according to the determinations of the International Society for the Study of Vascular Anomalies (ISSVA), divided into tumors and Vascular Malformations (VMs). Malformations can be simple (classified into capillaries, lymphatic or venous), combined to encompass larger vessels, or associated with other anomalies. Among the simple vascular malformations are varicose veins $[1,2]$.

Varicose veins are the most common oral vascular lesions in adults, especially in the older population [3]. The most commonly affected oral sites are the lips, tongue and buccal mucosa [4]. Clinically the lesions are flat or elevated, with color ranging from red to purple, influenced by their location, degree of vascular congestion and tissue depth [4]. Due to the possibility of progressive growth, this type of lesion is more likely to render local trauma, in addition to influencing oral function and aesthetics, especially in cases of large swelling [5].

Vascular lesions diagnosis can be made through physical exam and lesions analysis, which can also be associated with diascopy using a microscopic slide pressed against the vascular lesion. Other complementary exams may be helpful, such as fine needle aspiration, imaging examinations such as magnetic resonance and histopathological analysis [5]. There are several options for vascular lesions treatment, such as surgical excision, cryotherapy, chemotherapeutic agents, corticosteroids, embolization, radiofrequency ablation and sclerotherapy. Of these techniques, sclerotherapy is widely used because it is a safe and cost-effective option. This technique involves the insertion of a sclerosing substance, which causes a local inflammatory reaction with subsequent endothelial tissue fibrosis $[1,6,7]$. The use of sclerosing dilution in anesthetic solution may be an option to reduce transoperative burning, risk of tissue necrosis and to moderate the dose of the agent. However, despite the success of this technique, there is much variability in the concentration of the sclerosing agent and volume of the substance used [1].

Thus, this study evaluates the effectiveness of sclerotherapy protocols with different dilutions of $5 \%$ ethanolamine oleate in varicose veins treatment, emphasizing its clinical aspects after sessions.

\section{METHODS}

This study was retrospective and all participants with varicose veins (VV) attended the Stomatology Outpatient Clinic between 2014 and 2018 were selected. Twelve participants with VV were included, wherein two patients had two lesions, totaling 14 lesions. The VV diagnosis was made in accordance with the latest ISSVA (2018) classification for vascular anomalies based on clinical history and diascopy. Different protocols for the dilution of $5 \%$ Ethanolamine Oleate (EO) (Ethamolin ${ }$, Zest Pharma) were performed. When it occurred, the dilution was performed as follows: a) the patients were informed about the possibility of discomfort during and after the application of the medication; b) in a $1 \mathrm{ml}$ syringe, the dilution was made in a 1:20 ratio, using one part of Ethamolin and 19 parts of anesthetic (Alphacaine $100^{\circledR}$, Lidocaine $2 \%$ with epinephrine 1: 100.000, DFL); c) the patient was scheduled to return within 7 to 14 days to assess the need for a new application; d) a progressively increasing by $5 \%$ of the drug at each session. The recommendations for treatment included pain, growth, pressure, and aesthetic complaints. 
The demographic and clinical data collected in the medical records were: sex, age, skin color, diagnosis, initial lesion size, type, dose and concentration of the sclerosing agent, number of sclerotherapy sessions, undesired effect and lesion regression.

Regarding lesion regression, in order to make the evaluation of these data less subjective, the evaluation standard was established by determining a partial regression when a $50 \%$ reduction in initial diameter, together with the softening of the color and the reduction of the lesion volume, was observed clinically after the end of the sclerotherapy sessions. The regression was considered complete in cases where the affected mucosa fully achieved normal color and volume. The regression was considered null when there were no changes in clinical features.

Descriptive analysis of the studied variables was carried out through proportions (when variables were categorical) and means, standard deviations, minimummaximum values, mode and medians (when variables were numerical). This study was approved by the Ethical with the protocol 2019/3088378.

\section{RESULTS}

Female gender and white skin color prevailed with 7 (58\%) and 10 (83\%) participants. Age ranged from 14 to 79 years with an average of 47 years ( $S D=19$ years) and median of 48 years. Regarding the location of the 14 lesions, the buccal mucosa and the lower lip amounted for 8 (58\%) cases (table 1). Lesion size ranged from 0.5 to $20 \mathrm{~mm}$, with $8.4 \mathrm{~mm}$ on average $(\mathrm{SD}=7.2 \mathrm{~mm})$. Final volume of Ethamolin ${ }^{\circledR}$ varied from 0.4 to $4.3 \mathrm{ml}$, with $1.7 \mathrm{ml}$ on average $(\mathrm{SD}=1.0 \mathrm{ml})$. The drug concentration ranged from $5 \%$ to $100 \%$, with $24 \%$ as the average value ( $S D=23 \%$ ). The number of sessions ranged from 1 to 12 sessions with 5 sessions on average ( $\mathrm{SD}=3$ sessions). The number of points per application varied from 1 to 7 points with 4 points on average ( $\mathrm{SD}=1$ point). Regarding post-application pain and edema, they were observed in $43 \%$ and $29 \%$ of patients, respectively. Regarding the regression of the lesion, after the end of the applications, there were $6(43 \%)$ cases with complete regression and 8 (57\%) with partial regression. A patient dropped out of the course of treatment (table 2 and figure 1).

\section{DISCUSSION}

Vascular alterations are common in the oral mucosa and present themselves in a variable pattern at different ages. Diagnosis made through physical exam and lesion analysis, paired with the medical history, is effective to choose the therapeutic modality, and varies according to the specificities of the lesion and the degree

Table 1. Distribution of the 12 patients treated with sclerotherapy according to age, sex, skin color and lesion location.

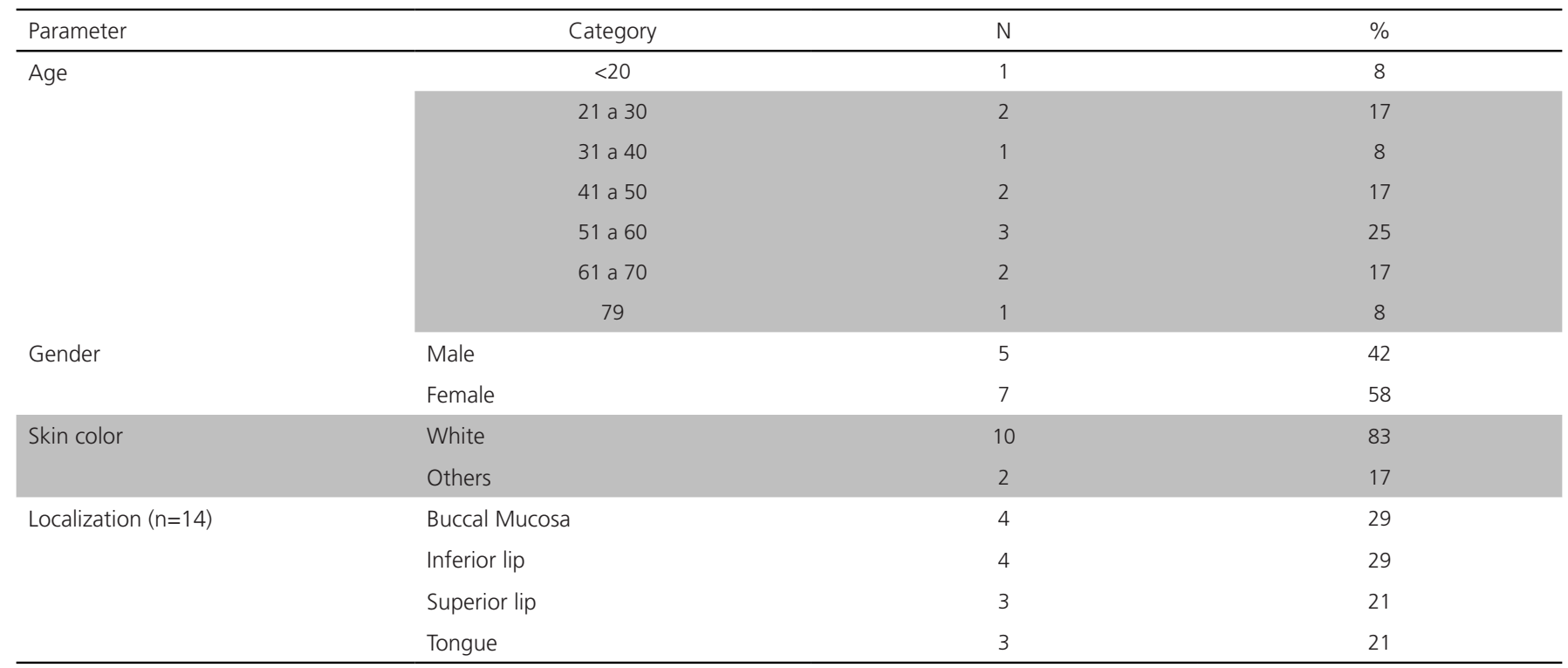


Table 2. Sclerotherapy data concerning the treatment of vascular lesions correlating size, number of sessions, number of applications (per session), total ethamolin average, minimum and maximum ethamolin concentration, symptoms, signs and lesion regression.

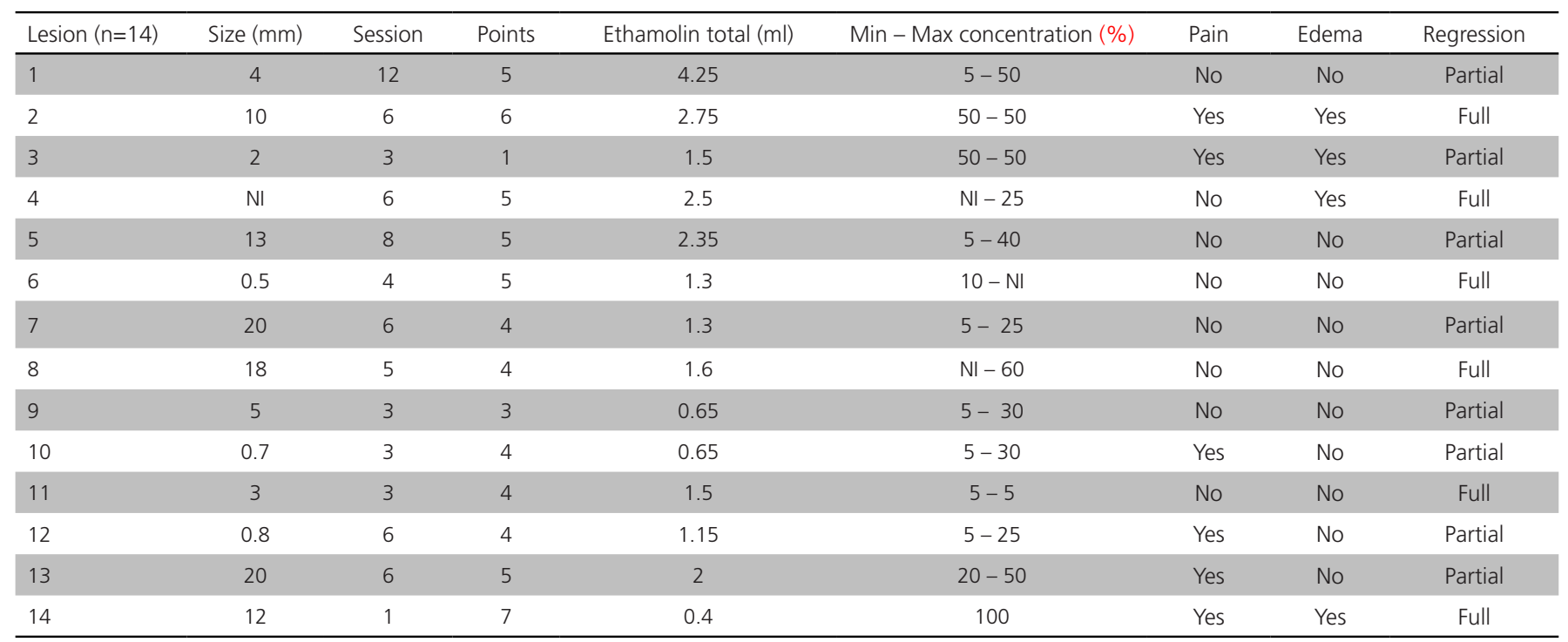

Note: Max: Maximum; Min: Minimum; NI: Not Informed.
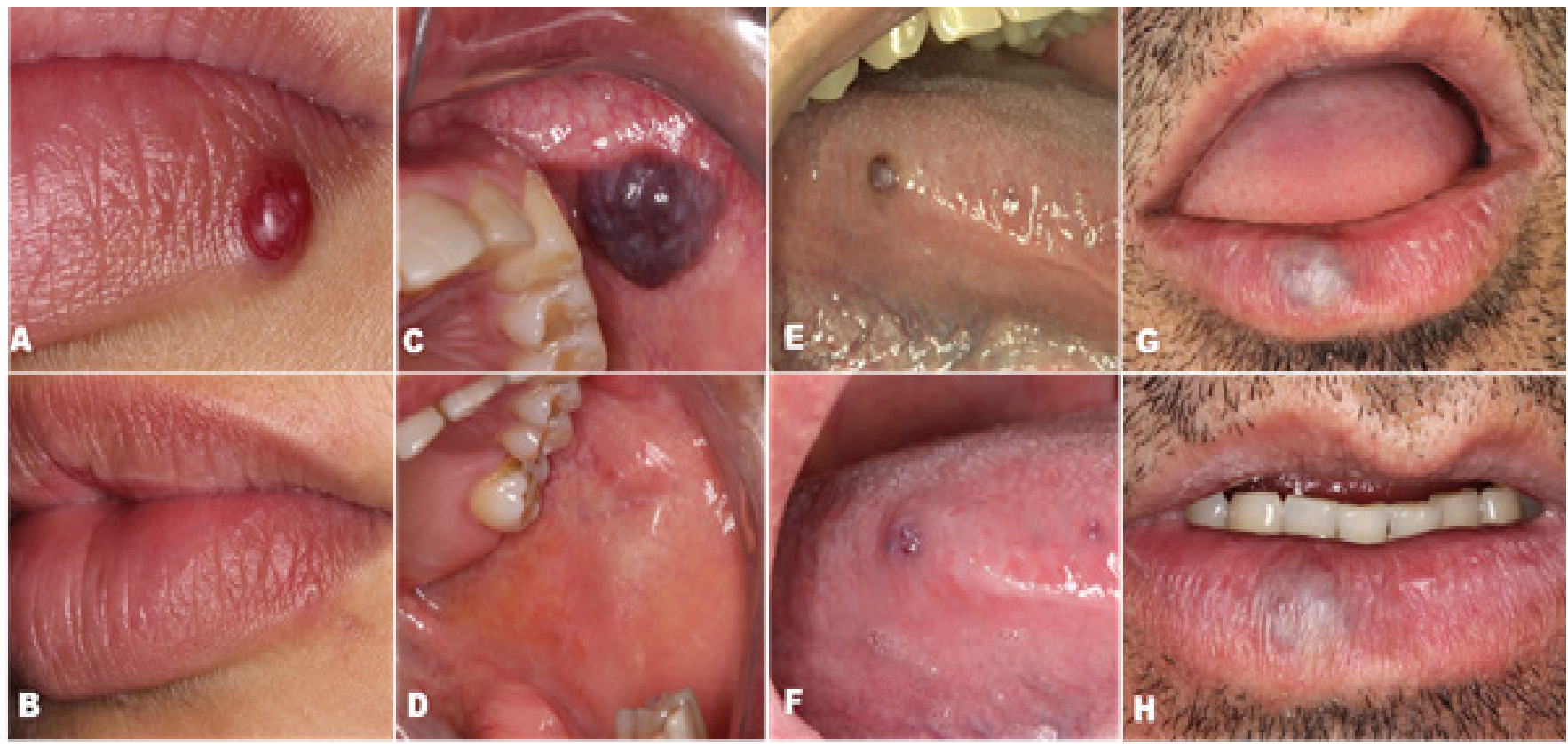

Figure 1. Clinical aspects of the lesions before and after sclerotherapy: $A$ and $B$ - Case 1: complete regression; $C$ and D - Case 2: complete regression; E and F - Case 3: partial regression; G and H - Case 4: partial regression.

of aesthetic and functional disfunction $[1,8,9]$. We showed that sclerotherapy with monoethanolamine oleate with concentration varying between $5 \%$ and $100 \%$ is a safe, practical and effective option for the treatment of this type of lesion.
In our cases, diascopy was the gold standard diagnostic test. Its choice is justified because it is a noninvasive and easy-to-perform method, optimizing the diagnostic process in the routine [10]. This widely used technique is usually reserved for more nonspecific cases 
and other methods, such as fine needle aspiration and imaging exams.

As described in the literature, there was a higher prevalence in females. This fact may suggest a note about the greater demand of women for diagnostic services and health care in general $[4,11]$. There is no research reporting a predilection for skin color in the occurrence of vascular lesions. Nonetheless, this study showed a high prevalence rate in white patients, which represented $83 \%$ of the total sample. It must be considered, however, that the predominant population where this study was carried out is descendants of Europeans.

Regarding the location, the higher number of lesions present on the buccal mucosa and lower lip stands out, totaling $58 \%$ of cases, as shown by Johann et al. in a 30 lesions study [8]. The great involvement of these areas may be related to the patient's perception, since it can generate aesthetic and functional impairment as well as discomfort when traumatized, leading to the demand for treatment. It is particularly noteworthy that on the lip, the lesion also presents greater diagnostic detection by the professional, who can more easily ask the patient about the lesion and propose a treatment.

The size of this kind of lesion is quite variable [12]. In this study, a great variability in the extension of the lesions could be observed, varying from $0.5 \mathrm{~mm}$ to $20 \mathrm{~mm}$. A large variation in the number of applications necessary to induce lesion regression of different extensions was also observed, requiring a more detailed assessment of the protocols of each case to determine the factors that influence the presence or absence of faster lesion reduction according to its dimensions.

There are several sclerosing agents on the market that perform the function of generating tissue fibrosis and resulting in vessel occlusion. Monoethanolamine oleate (Ethamolin ${ }^{\circledR}$ ) was used for sclerotherapy in the study cases due to its low cost, efficacy and safety. The literature is not unanimous regarding the dilution of sclerosing agents or even its need. Studies that do not use dilution demonstrate a reduction in the number of sessions, optimizing treatment and obtaining satisfactory results, but with tissue necrosis risk. However, in the presence of dilution, there is a decrease in chemical action on the vascular wall, requiring a higher number of applications but resulting in lower risk of necrosis. The procedures vary between the use of distilled water, saline and anesthetic solution $[4,13]$. Dilution in anesthetic solution, as was done in this study, provides relief from transoperative burning. All analyzed cases were diluted in 2\% lidocaine with epinephrine 1:100,000, except in one case which presented severe burning during application and postoperative hematoma. In this study, the application of monoethanolamine oleate started with a concentration of $5 \%$ of the drug in lesions smaller than

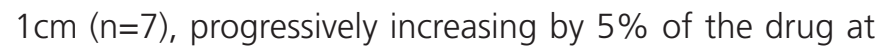
each session. A concentration of $50 \%$ was used in three lesions and $100 \%$ monoethanolamine oleate was applied in only one lesion above $1 \mathrm{~cm}$. An initial protocol with $5 \%$ Ethamolin ${ }^{\circledR}$ can be established as a safety measure for the analysis of the patient's immune response to the drug, which is associated with the monitoring and recording of adverse reactions that may be presented in case of hypersensitivity manifesting before or during treatment. The number of points required for intralesional application depends on the extent of vascular abnormality. For this study, the use of four perilesional points and one central point was determined in most cases, being decreased or increased according to the need seen by the operator. Kato et al. stated that a single puncture may not be enough to dissipate the agent throughout the lesion, which suggests the need for varied punctures to allow the medication to reach the lesion in all its extension and depth [13]. Kato et al. [14] showed that the concentration of $5 \%$ Ethamolin $®$ performed better than $1.25 \%$ and $2.5 \%$ for sclerotherapy of oral vascular lesions measuring up to $20 \mathrm{~mm}$.

The number of sclerotherapy sessions varies widely, with an average of 5 sessions. kato et al. describe as a determining point for the treatment to conduct interspersed applications with a minimum interval of seven days between them, with injections of up to $2 \mathrm{ml}$ [13]. However, Kato et al. [13] noted the possibility of the patient giving up when opting for a treatment with more than two sessions. Complete lesion regression and patient satisfaction are used as the main parameters for the suspension of the medication. There was only one case of withdrawal due to the duration of the treatment, where the participant chose to interrupt the applications in the seventh session. In cases where applications ended without complete regression of the lesion, patients reported satisfaction with the results achieved and data for follow-up were recorded in the medical records.

Queiroz et al. [15] emphasized the main adverse reactions related to monoethanolamine oleate, which can be painful during the procedure, erythema, tissue necrosis 
and allergic reaction. In this sample, the main effects found were pain and edema, wherein spontaneous regression was always observable and, when necessary, the use of routine analgesic was associated. However, pain measurement is subjective, as the patient's response is binary ("yes" or "no"), making it impossible to obtain a numerical scale $[15,16]$. The use of techniques such as the Visual Analogue Scale (VAS) could assist in this data [17].

\section{CONCLUSION}

Vascular lesions occur mainly in white and middleaged women, manifesting as purplish nodules on the lip and cheek mucosa. Sclerotherapy with monoethanolamine oleate with concentration varying between $5 \%$ and $100 \%$ is a safe, practical and effective option for the treatment of this type of lesion, as it is able to clinically achieve total lesion regression and provide the patient with aesthetic satisfaction and reestablishing the region's original function.

\section{Collaborators}

BM MORAES: substantial contributions to the conception or design of the work; the acquisition, and interpretation of data for the work; Drafting the work and revising it critically for important intellectual content; Final approval of the version to be published. MM ARÊDES: substantial contributions to the analysis and interpretation of data for the work; Revising it critically for important intellectual content; Final approval of the version to be published. CMM VILAÇA, MCLIM BARKI, and KBFC FONTES; revising it critically for important intellectual content; Final approval of the version to be published. JT WERNECK and BLS PICCIANI: contributions to the conception or design of the work; the acquisition, and interpretation of data for the work; Revising it critically for important intellectual content; Final approval of the version to be published.

\section{REFERENCES}

1. Ribeiro MC, Grossmann SMC, Amaral MBF, Castro WH, Navarro TP, Procopio RJ, et al. Effectiveness and safety of foam sclerotherapy with $5 \%$ ethanolamine oleate in the treatment of low-flow venous malformations in the head and neck region: a case series. Int J Oral Maxillofac Surg. 2018;47:900-907.

2. ISSVA Classification of Vascular Anomalies (C2018. International Society for the Study of Vascular Anomalies. [cited 2019 July 20]. Available from: www.issva.org/ classification.
3. McNamara KK, Kalmar JR. Erythematous and vascular oral mucosal lesions: a clinicopathologic review of red entities. Head Neck Pathol. 2019;13:4-15.

4. Fernandes DT, Elias RA, Santos-Silva AR, Vargas PA, Lopes MA. Benign oral vascular lesions treated by sclerotherapy with ethanolamine oleate: A retrospective study of 43 patients. Med Oral Patol Oral Cir Bucal. 2018;23:108-117.

5. Jaeger F, Alvarenga RL, Galizes BF, Girardi GP, Alvarenga GL, Leal RM. Sclerotherapy of oral hemangioma with 5\% ethanolamine oleate: Clinical report. Rev Port Estomatol Med Dent Cir Maxilofac. 2013;54:91-94.

6. Horbach SE, Lokhorst MM, Saeed P, de Goüyon Matignon de Pontouraude CM, Rothová A, Van der Horst CM. Sclerotherapy for low-flow vascular malformations of the head and neck: A systematic review of sclerosing agents. J Plast Reconstr Aesthet Surg. 2016;69:295-304.

7. Manzano BR, Premoli AM, Santaella NG, Ikuta CR, Rubira CM, da Silva Santos PS. Sclerotherapy as an esthetic indication in oral vascular malformations: a case series. An Bras Dermatol. 2019;94:521-526.

8. Johann AC, Aguiar MC, do Carmo MA, Gomez RS, Castro $\mathrm{WH}$, Mesquita RA. Sclerotherapy of benign oral vascular lesion with ethanolamine oleate: An open clinical trial with 30 lesions. Oral Surg Oral Med Oral Pathol Oral Radiol Endod. 2005; 100:579-584.

9. Zanettini I, Zanettini RM, Gollo R. Sclerotherapy as an alternative treatment fororal vascular pathologies. Clin Pesq Odontol. 2005;2:119-126.

10. da Silva WB, Ribeiro AL, de Menezes SA, de Jesus Viana Pinheiro J, de Melo Alves-Junior S. Oral capillary hemangioma: a clinical protocol of diagnosis and treatment in adults. Oral Maxillofac Surg. 2014;18:431-437.

11. Gomes R, Nascimento EF, Araújo FC. Why do men use the health services less than women? Explanations by men with low versus higher education. Cad Saude Publica. 2007;23:565-574.

12. Kaban LB, Mulliken JB. Vascular anomalies of maxillofacial region. J Oral Maxillofac Surg. 1986;44:203-213.

13. Kato CNAO, Ribeiro MC, do Amaral MBF, Grossmann SMC, de Aguiar MCF, Mesquita RA. Experience with 5\% ethanolamine oleate for sclerotherapy of oral vascular anomalies: A cohort of 15 consecutive patients. J Craniomaxillofac Surg. 2019;47:106-111.

14. Kato CNAO, Ribeiro MC, Abreu MH, Grossmann SD, Abreu LG, Caldeira PC, et al. What is the preferred concentration of ethanolamine oleate for sclerotherapy of oral vascular anomalies? Med Oral Patol Oral Cir Bucal. 2020;25:e468-e473.

15. de Queiroz SB, de Lima VN, Amorim PH, Statkievicz C, Magro-Filho O. Severe Edema After Sclerotherapy of Labial Hemangioma with Ethamolin Oleate in a Young Child. J Craniofac Surg. 2016;27:e567-e568. 
16. Stuepp RT, Scotti FM, Melo G, Munhoz EA, Modolo F. Effects of sclerosing agents on head and neck hemangiomas: a systematic review. J Clin Exp Dent. 2019;11:e1033-1044.

17. Fernandes DT, Hebling E, Santos-Silva AR, Lopes MA. A series of 33 older patients with lip venous lake treated by sclerotherapy.
Int J Dermatol. 2019. https://dx.doi.org/10.1111/ijd.14479. Epub ahead of print. PMID: 31074017.

Received on: 16/6/2020 Final version resubmitted on: 15/8/2020 Approved on: 10/8/2020 